\title{
Performances of dead-end ultrafiltration of seawater: from the filtration and backwash efficiencies to the membrane fouling mechanisms
}

\author{
Massé Anthony ${ }^{1,{ }^{*}}$, Arab Oumnia ${ }^{1}$, Séchet Véronique ${ }^{2}$, Jaouen Pascal ${ }^{1}$, Pontié Maxime ${ }^{1}$, \\ Sabiri Nour-Eddine ${ }^{1}$, Plantier Séverine ${ }^{1}$
}

${ }^{1}$ LUNAM, Université de Nantes, GEPEA, UMR-CNRS 6144, 37 Bd Université, BP 406, 44602 Saint-

Nazaire Cédex, France

2 Ifremer, Laboratoire Phycotoxines, Centre de Nantes, BP 21105, 44311, Nantes, France

* Corresponding author : Anthony Massé, email address : anthony.masse@univ-nantes.fr

\begin{abstract}
:
The present work investigates the fouling mechanisms of PVDF hollow fibre membrane $(0.03 \mu \mathrm{m})$ during the dead end ultrafiltration at a fixed permeate flux (outside to inside configuration) of complex synthetic seawater composed by humic acids, alginic acids, inorganic particles and numerous salts at high concentrations. Short term ultrafiltration experiments at 100 L.h-1.m-2 show that the optimal specific filtered volume seems to be equal to 50 L.m-2. A residual fouling resistance equal to $2.1010 \mathrm{~m}$ 1 is added after each cycle of filtration during $8 \mathrm{~h}$ of ultrafiltration at 100 L.h-1.m-2 and 50 L.m-2. Most of the fouling is reversible $(80 \%)$. Organics are barely (15\% of humic acids) retained by the membrane. Backwash efficiency drops during operation which induces less organics into backwash waters. Humic acids could preferentially accumulate on the membrane early in the ultrafiltration and alginic acids after the build-up of a fouling pre-layer. Colloids and particulates could accumulate inside a heterogeneous fouling layer and/or the concentrate compartment of the membrane module before being more largely recovered inside backwash waters.
\end{abstract}




\section{Graphical abstract}

Graphical abstract of fouling mechanisms during ultrafiltration of the synthetic seawater (TOC: total organic carbon, OC-HA organic carbon from humic acids, OC-Alg: organic carbon from alginic acids).

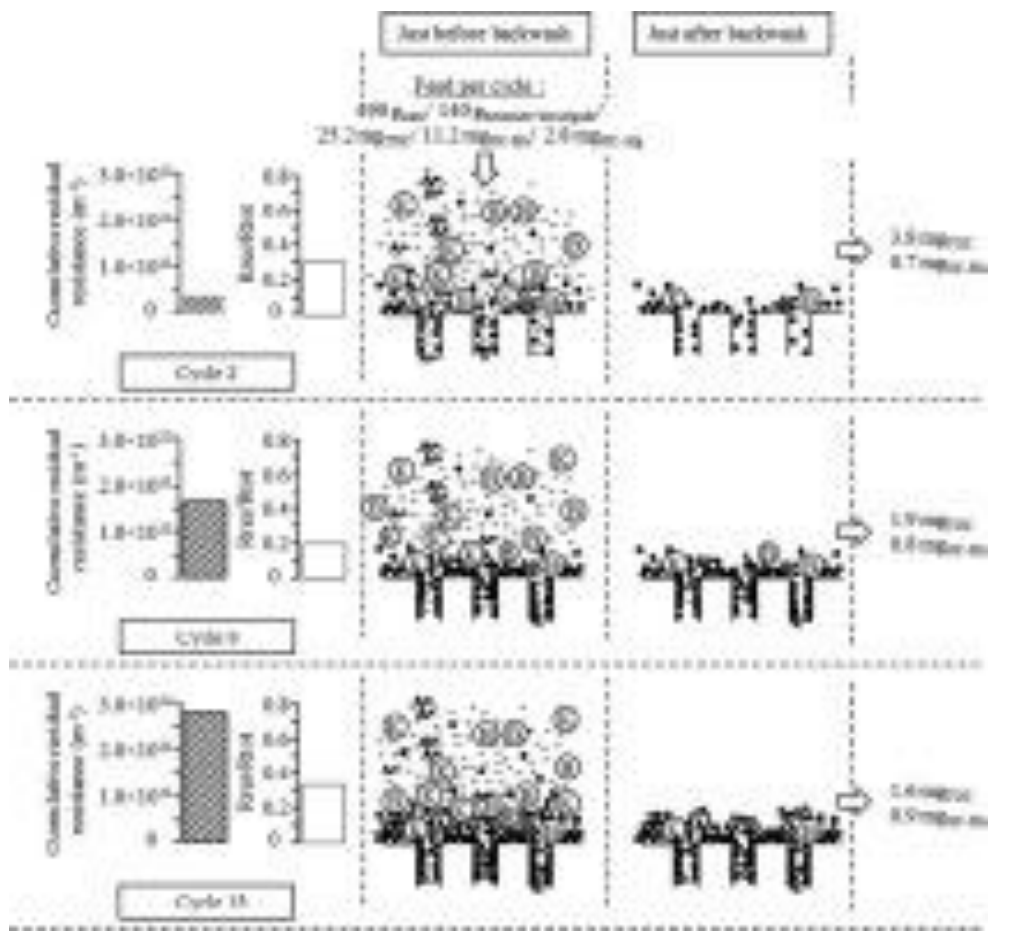

\section{Highlights}

- Sustainable Ultrafiltration of seawater from a specific filtered volume. Low residual resistance (less than $20 \%$ of total fouling resistance). Fouling layer fairly permeable to low molecular weight compounds as humic acids. Alginic acids more and more retained on membrane surface over the ultrafiltration. Fouling pre-layer mainly formed by humics and alginic acids for subsequent layers.

Keywords : Seawater, Ultrafiltration, Fouling membrane, Alginic acids, Humic acids 


\section{Introduction}

Ultra- and Microfiltration membranes are widely used for seawater treatment instead of or after granular filters located at aquaculture or desalination plants [1-6]. Porous membrane units are often more compact than conventional sand filtration ones [7, 8] and allow to limit the (bio)-fouling of downstream units such as Reverse Osmosis (RO) membranes, and therefore the volume of chemicals used [9]. Moreover, Ultra- and Microfiltration enable a constant and good quality of the produced water [8, 10, 11]. Pretreatment by Ultrafiltration can represent $10-40 \%$ of the total energy consumption of RO desalination plants [9]. The total cost of a RO plant can be $2-7 \%$ lower in the case of an UF pretreatment comparatively to a sand filter one [9]. Nevertheless, the mitigation of UF membrane fouling remains a key issue for sustainable operation of desalination plants.

Two modes of dead-end membrane ultrafiltration are widely used for the pretreatment of seawater: filtration under pressure from the lumen of fibers to the exterior or in the opposite direction and filtration by suction with submerged membranes [9]. Polyvinylidene fluoride, polysulfone or polyethersulfone membranes are often used [12, 13]. Permeate and backwash fluxes range from 20 to $150 \mathrm{~L} \cdot \mathrm{h}^{-1} \cdot \mathrm{m}^{-2}$ and from 60 to $350 \mathrm{~L} \cdot \mathrm{h}^{-1} \cdot \mathrm{m}^{-2}$ respectively and are usually encountered for seawater pretreatment by porous membranes [14-16]. Backwash and filtration cycles can last from a few seconds and up to several minutes or hours respectively $[17,18]$. Therefore, the present work deals with the fouling mechanisms of membranes during seawater ultrafiltration in dead-end mode (from the outside to the inside of the PVDF hollow fiber membrane). The mass balances were carried out by considering the backwash waters and permeates. Thus, it is possible to identify at any time of the filtration, the compounds that participate to the membrane fouling. Hence, the changes of fouling behavior could be monitored.

Characteristics of natural seawater vary according to season, weather, tide, location, etc. Seawater is mostly composed of water (96\%). The remaining $4 \%$ are dissolved and particulate organics or minerals such as polysaccharides, proteins, humics, phytoplankton, salts, etc. On average, the salinity ranges from 25 to 45 g. $\mathrm{L}^{-1}$. The marine organic carbon is mainly ( $\left.>92 \%\right)$ present in dissolved form (DOC). The particulate organic carbon represents $2-8 \%$ of the total organic carbon (TOC); the living part of the particulate organic carbon (POC) is very small except during algal blooms. On average, the concentrations of particulate organic carbon and nitrogen in coastal waters or surface waters are between 0.01 and $1 \mathrm{mg} \mathrm{L}^{-1}$; much higher concentrations are frequently found in marine phytoplankton blooms. DOC concentration 
ranges from 0.5 to $20 \mathrm{mg} . \mathrm{L}^{-1}$ for coastal seawater can be found [19-21]. Colloidal and soluble organics can be released by phytoplankton and/or result from cell lysis, solubilization of particles, etc. Humic substances constitute a part of this matter (60 to 80\% of DOC) [22], which are themselves divided into fulvic acids (80\%) and humic acids (20\%). Sugars represent around $10 \%$ of DOC meaning a few hundred micrograms per liter of seawater. They come mainly from phytoplankton [23] and include sugars such as glucose, fructose, galactose, mannose and xylose [20, 24]. Finally, the lipids are found in trace amounts. As a matter of fact, due to this high variability of natural seawater composition, it is difficult to repeat similar filtration experiments unless several plants operate in parallel. In fact, an infinite change in the process control or seawater composition can induce huge changes on fouling. As a consequence, membrane fouling behavior can not be attributed to a defined parameter. For the present study, the ultrafiltration experiments of the synthetic seawater are replicated. Based on the average composition of natural seawater, a synthetic and reproducible saline suspension is prepared. Special attention is paid to the reconstitution of seawater's organic matter and more particularly the polysaccharides and humic substances due to their significant fouling potential [25-31]. Moreover, the fouling potential of organic matter changes in the presence of salts due to the change of interactions between the compounds and the membrane [27, 29-35]. Thus, divalent ions of seawater could significantly increase the fouling by the organic matter [36]. Therefore, several types of ions are added to the synthetic seawater.

For the present work, the fouling mechanisms of an ultrafiltration membrane are studied for a (i) high salinity mixture with organic and inorganic multi components rather than only one or two components (ii) hollow fiber dead-end filtration with fluxes as well as duration of filtration and backwash cycles in the range of values to those found for the industrial plants (iii) long term ultrafiltrations respectively for a lab scale. Critical conditions of synthetic seawater ultrafiltration are determined thanks to short term experiments. These critical conditions are chosen for longer experiments of ultrafiltration (8h) in order to study the fouling behavior.

\section{Material and methods}

\subsection{Synthetic seawater preparation}

Natural seawater contains the same families of components all over the world. However, the contents of the compounds vary according to tides, seasons, temperatures, regions, weather, etc. (Table 1). 


\section{Insert table 1}

Therefore, synthetic seawater, as much as possible reproducible, is prepared in order to carry out several experiments with similar conditions and define an average behavior of the UF (Table 1). Synthetic seawater should take into account both mineral and especially organic compounds (from particulate to dissolved compounds) since the latter pose big problems of fouling on reverse osmosis pre-treatment $[22,41]$. For each class of compounds, mineral and organic, one compound was selected as a model.

\subsubsection{Mineral matters - Dissolved fraction}

Most of the research on membrane fouling is performed with lightly salted solutions or with only one or two salts $[27,29,31,42]$. For the present study, Instant ocean $^{\mathrm{TM}}$ salts are dissolved in osmosed water in order to obtain a concentration of $35 \mathrm{~g}_{\text {salts. }} \mathrm{L}^{-1}$. These salts are regularly used for aquariums in order to obtain a reproducible ionic composition with several salts.

\subsubsection{Mineral matters - Particulate fraction}

Bentonite from Riedel de Haën has been selected as model for particulate mineral material. It is already present in natural water and has a size inferior to $200 \mu \mathrm{m}$. Kieselguhr, a silica-based mineral, is also added to the synthetic seawater. This diatom is largely present in natural seawater. Both bentonite and kieselguhr are maintained in an oven at $100^{\circ} \mathrm{C}$ before the preparation of synthetic seawater and $5 \mathrm{mg} . \mathrm{L}^{-1}$ of each are used for seawater reconstitution.

\subsubsection{Organic matters - Dissolved/colloidal fraction}

Dissolved and colloidal organic matters (DOM) are mainly composed of humic substances and polysaccharides. They are strongly involved in the fouling of reverse osmosis and ultrafiltration membranes of seawater desalination plants [43, 44]. Humic and alginic acids are selected as model compounds.

A concentrated solution of humic acid is prepared. One gram of humic acid (HA) (supplied by Acros Organics) is added to $500 \mathrm{~mL}$ of osmosed water. Then, $62.4 \mathrm{~mL}$ of $\mathrm{NaOH}$ solution $(2 \mathrm{~N})$ are added before completing up to one liter with osmosed water and stirring for $24 \mathrm{~h}$ in the dark. One liter of this concentrated suspension is added to $1 \mathrm{~L}$ of Instant ocean ${ }^{\mathrm{TM}}$ salted water at $70 \mathrm{~g}_{\text {salts }} / \mathrm{L}$. Finally, the $\mathrm{pH}$ is adjusted to $7-8$ by addition of $\mathrm{HCl}(2 \mathrm{~N})$ and the solution is filtered through GF/F Whatman filters $(0.7 \mu \mathrm{m})$ in order to retain the complexes (particles) 
formed between humic acids and salts. The filtrate is recovered and represents the acid humic stock solution which is stored in the dark at $4^{\circ} \mathrm{C}$ during less than $24 \mathrm{~h}$ before the preparation of synthetic seawater.

An alginic acid stock solution is also prepared. Thirty five grams of Instant ocean ${ }^{\mathrm{TM}}$ salts are dissolved in $500 \mathrm{~mL}$ of osmosed water. Then, 0.2 gram of alginic acid (supplied by Sigma Aldrich) is introduced before completing up to $1 \mathrm{~L}$ with osmosed water. Finally, the suspension is filtered with a $0.7 \mu \mathrm{m} \mathrm{GF} / \mathrm{F}$ Whatman filter and stored at $4{ }^{\circ} \mathrm{C}$. It represents the alginic acid stock solution.

The organic carbon concentration of humic and alginic acid stock solutions is determined the day before each synthetic seawater preparation in order to determine volumes to be added in order to obtain the suitable concentrations $\left(0.8 \mathrm{mg}_{\mathrm{C}} \cdot \mathrm{L}^{-1}\right.$ for humic acids and $0.2 \mathrm{mg}_{\mathrm{C}} \cdot \mathrm{L}^{-1}$ for alginic acids). Humic and then alginic acids are added after bentonite and kieselguhr during the synthetic seawater preparation.

The synthetic seawater was prepared 4 times with a composition similar to a natural one (Table 1). It is worth noting that TOC concentration of synthetic seawater is higher than organic carbon concentration coming from humic plus alginic acids. A part of this surplus of organic carbon can come from dusts, residuals (cleaning chemicals, organic matter from the last experiment), osmosed water which is used for the reconstitution of seawater, etc.

\subsection{Experimental set-up:}

The pilot plant (Fig. 1) is equipped with a volumetric membrane pump (Grundfos DMX 221) which allows the feeding of the external side of the hollow fiber membrane with seawater. Pressure and temperature sensors (Wika - accuracy: $0.5-1 \%$ of span) are located before the module $(0-2.5$ bar $)$ and in the permeate exit ( $0-4$ bar). Permeate and backwash flowrates are measured thanks to an electromagnetic flowmeter (Techfluid-Flomid 0 FX). Pressure is applied on a balloon located downstream from the membrane module and filled by osmosed water, when backwash is planned. Specific filtered volumes (permeate flux multiplied by time of filtration) are comprised between 25 to $100 \mathrm{~L} \cdot \mathrm{m}^{-2}$ at $100 \mathrm{~L} \cdot \mathrm{h}^{-1} \cdot \mathrm{m}^{-2}$ and backwash fluxes are set to $340 \mathrm{~L} \cdot \mathrm{h}^{-1} \cdot \mathrm{m}^{-2}$ during 30 seconds. Each filtration sequence includes a filtration step followed by 5 seconds of relaxation then 30 seconds of backwash and a final step of 5 seconds of relaxation before beginning another sequence. As reminded in the introduction of this article, operating conditions (flux values, duration of cycles, membrane material, mode of filtration, etc.,) correspond to the ones classically encountered in the desalination plants. For the present study, 4 (for short term experiments) or 16 cycles of filtration (for experiments of 
8h) are carried out, in dead-end mode from the outside to the inside of hollow fiber membrane. Surface of polyvinylidene difluoride (PVDF) membrane is equal to $0.28 \mathrm{~m}^{2}$ and the mean pore diameter is equal to $0.03 \mu \mathrm{m}$.

\section{Insert Fig 1}

\section{$\underline{2.3 \text { Sampling and analysis: }}$}

During all the duration of ultrafiltration, synthetic seawater of feed tank is continuously mixed. The composition of feed water remains constant during the ultrafiltration. Feed water is sampled before and during each trial in order to determine organic carbon, turbidity, $\mathrm{UV}_{254 \mathrm{~nm}}$. Permeates and water from backwashes are collected in vials previously washed and stored at $450^{\circ} \mathrm{C}$ during one night in order to be decontaminated.

During long term experiments, at the end of a filtration sequence (one cycle of filtration followed by one cycle of backwash), the whole permeate and backwash waters corresponding to this sequence are sampled and analyzed. It concerns the sequences numbered 5 to 16 for the permeate waters and $2,3,5,6,8,9,11,12,14,15$ for the backwash ones. Otherwise, the samples which correspond to the filtration cycles numbered 1 to 4 or numbered $4,7,10,13$, 16 for the permeate and backwash waters respectively, are taken each and during five minutes or seconds respectively.

Turbidity is measured with HACH 2100AN Turbidimeter. Ionic chromatography is used to measure the ion concentration. It is composed of two units, D-120 and ICS-900, each associated with an ion exchange resin (stationary phase), one for the cations and the other for anions. Sulfuric acid $(17 \mathrm{mM})$ and sodium carbonate $(9 \mathrm{mM})$ solutions are used as eluent (mobile phase) for the anionic and cationic chromatography. Detection is carried out by conductivity and concentrations are determined using internal standards. Data are transferred to the computer with Chromeleon software Version 6.0. All samples are filtered to $0.45 \mu \mathrm{m}$ before measurement by ionic chromatography. Total organic carbon (TOC) is analyzed with Shimazu TOC-L. Dissolved Organic Carbon (DOC) is obtained after the filtration of sample at $0.7 \mu \mathrm{m}$. Humic acids (HA) are aromatic compounds which absorb at $254 \mathrm{~nm}$. The absorbance measurements at $254 \mathrm{~nm}$ are performed using a UV/Visible spectrophotometer from Perkin Elmer. HA calibration curves are carried out with saline standard solutions $\left(35 \mathrm{~g}_{\text {salt }} / \mathrm{L}\right)$. The Silt Density Index is determined at 2.1 bars according to ASTM D-4189-95 standard. It is defined as follows (equation 1): 


$$
S D I_{(\% / \min )}=\frac{100\left(1-t_{0} / t_{F}\right)}{t_{T}}
$$

With $\mathrm{t}_{0}$, the time required to filter the first $500 \mathrm{~mL}$ of the suspension (s), $t_{F}$, the time (s) required to obtain $500 \mathrm{~mL}$ of permeate after a period of time equal to $t_{T}$ (min), usually 15 minutes.

Millipore $0.45 \mu \mathrm{m}$ nitrocellulose membrane (Ref. HAWP 04700) is used for SDI measurements.

\subsection{Fouling resistance definition and calculation}

The permeate flux $\left(\mathrm{J}_{\mathrm{p}}\right)$ and the transmembrane pressures (TMP) are used for the calculation of total resistance and then fouling resistance $\left(R_{\text {foul }}\right)$ knowing the membrane resistance $\left(R_{m}\right)$ (equation 2):

$$
J_{p}=\frac{T M P}{\mu *\left(R_{m}+R_{\text {foul. }}\right)}
$$

The viscosity of salted permeate at $20^{\circ} \mathrm{C}(\mu)$ is taken to $1.08 \times 10^{-3}$ Pa.s. For each filtration cycle, the fouling resistance $\left(\mathrm{R}_{\text {foul. }}\right)$ is defined as the sum of two terms, a reversible fouling $\left(\mathrm{R}_{\text {rev }}\right)$ which can be removed thanks to a backwash and a residual fouling $\left(\mathrm{R}_{\text {res }}\right)$ resistance which remains after backwash (Fig. 2)

\section{Insert Fig 2}

Reversible and residual fouling resistances can be calculated for the cycle (n) by using the equation numbered $3,4,5$ :

$$
\begin{gathered}
R_{\text {foul. }}(n)=R_{f}(n)-R_{i}(n)=R_{\text {rev }}(n)+R_{\text {res }}(n) \\
R_{\text {rev }}(n)=R_{f}(n)-R_{i}(n+1) \\
R_{\text {res }}(n)=R_{i}(n+1)-R_{i}(n)
\end{gathered}
$$


The indexes $\mathrm{i}$ and $\mathrm{f}$ refer to the initial and final fouling resistance during one cycle of filtration.

\section{Results}

\subsection{Study of critical conditions on short term ultrafiltrations}

Concerning short term experiments, 4 cycles of filtration are successively done, each one intersected by backwash at $250 \mathrm{~L} \cdot \mathrm{h}^{-1} \cdot \mathrm{m}^{-2}$ during 30 seconds. Different specific filtered volumes per cycle of filtration (SFV) are tested: $25,50,75$ and $100 \mathrm{~L} . \mathrm{m}^{-2}$ meaning a filtration cycle duration of $0.25,0.5,0.75,1 \mathrm{~h}$ at the permeate flux of $100 \mathrm{~L} \cdot \mathrm{h}^{-1} \cdot \mathrm{m}^{-2}$. This value of permeate flux is in the range of those classically encountered for ultrafiltration of seawater on a large scale. These experiments aim to choose, for longer term experiments, the SFV below which few residual fouling will be observed in order to have a sustainable operation.

Changes of normalized permeability $\left(\mathrm{Lp}_{\left(20{ }^{\circ} \mathrm{C}\right)} / \mathrm{Lp}_{0\left(20{ }^{\circ} \mathrm{C}\right)}\right)$ during 4 cycles of filtration are shown in figure 3 . Results for ultrafiltration of synthetic and natural seawater sampled at Le Croisic (Atlantic Ocean - France) are gathered.

\section{Insert Fig 3}

Few changes of normalized permeability are observed during the ultrafiltration of synthetic seawater to a specific filtered volume equal to $25 \mathrm{~L} . \mathrm{m}^{-2}$. However, the permeability drops from one cycle to another for 50, 75 and $100 \mathrm{~L} . \mathrm{m}^{-2}$ which means membrane fouling during ultrafiltration. For specific volume equal to $100 \mathrm{~L} . \mathrm{m}^{-2}$, the backwashes do not allow recovering the initial permeability; the filtration operates above critical conditions. For 75 L. $\mathrm{m}^{-2}$, the normalized permeability decreases drastically during each cycle of filtration meaning an increase of transmembrane pressure since the permeate flux is fixed to $100 \mathrm{~L} . \mathrm{h}^{-}$ ${ }^{1} \cdot \mathrm{m}^{-2}$. Hence, the maximum pressure before membrane module breakage could be rapidly exceeded beyond four cycles of ultrafiltration. At $50 \mathrm{~L} . \mathrm{m}^{-2}$, the ultrafiltration seems to operate close to the critical conditions since few residual fouling is observed. For this condition, synthetic seawater is compared to a natural one during four cycles of ultrafiltration (Fig. $3 b$ ). Normalized permeability decreases and contrary to the synthetic seawater an important residual fouling remains after backwashes. It is worth noting that the present behavior of natural seawater ultrafiltration will change according to the day, the season, the weather, the tide, etc. because the composition of water will change. Therefore, it is difficult to define generic optimal operating conditions for ultrafiltration of natural seawater. 
In conclusion, for the remainder of this study, the fouling mechanisms will be studied, during long term ultrafiltration ( 8 hours) of synthetic seawater when the specific filtered volume will be equal to $50 \mathrm{~L} \cdot \mathrm{m}^{-2}$ at a permeate flux of $100 \mathrm{~L} \cdot \mathrm{h}^{-1} \cdot \mathrm{m}^{-2}$.

\subsection{Filtration efficiency and fouling mechanisms during $8 \mathrm{~h}$ of ultrafiltration}

\subsubsection{Hydraulic performances}

Changes of fouling resistance during ultrafiltration are shown in figure 4.

\section{Insert Fig 4}

The average fouling resistance increases slowly from the beginning to the end of operation where it reaches around $3.10^{11} \mathrm{~m}^{-1}$. So, the fouling velocity is approximately equal to $6.10^{8} \mathrm{~m}^{-}$ ${ }^{1} \cdot \mathrm{min}^{-1}$ during the $8 \mathrm{~h}$ of the filtration period. The fouling resistance at the end of the first filtration cycle, meaning before any backwashes, is of the same order of magnitude as the one found by Castaing et al. [45] after the same time of dead-end microfiltration $(0.2 \mu \mathrm{m})$ of a seawater containing 1000 microalgae. $\mathrm{L}^{-1}$, meaning a total organic carbon concentration close to this study (around $2 \mathrm{mg} . \mathrm{L}^{-1}$ ).

For each cycle of filtration, the fouling resistance divides into residual and reversible ones as defined in the material and methods paragraph (Fig. 5).

\section{Insert Fig 5}

As already remarked with experiments performed on 4 cycles of filtration (Fig. 3), few residual fouling accumulates and the cumulative residual fouling resistance increases quasi linearly during filtration. The backwashes do not allow removing all the foulants of the membrane surface which is why a residual fouling resistance equal to approximately $2.10^{10} \mathrm{~m}^{-}$ 1 is added at each cycle. Most of the fouling is reversible since, on average, only $20 \%$ of fouling remain after a backwash. No residual fouling is observed after the first cycle of filtration (Fig 5).

\subsubsection{Quality of the produced water}

The average size of bentonite and kieselguhr is equal to $17-21 \mu \mathrm{m}$ [46]. Hence, these particles are fully retained by the membrane and can't participate in the turbidity and $\mathrm{SDI}_{15}$ of permeates contrary to organics and salts alone or recombined together (Fig. 6). 


\section{Insert Fig 6}

The values of $\mathrm{SDI}_{15}$ and turbidity of permeates vary between 2.0 and $3.5 \% \cdot \mathrm{min}^{-1}$ (average equal to $2.6 \%$. $\min ^{-1}$ ) and 0.1 to 0.4 NTU respectively; more than $6.6 \% \cdot \mathrm{min}^{-1}$ and $3.1 \mathrm{NTU}$ are found for the feeding. The $\mathrm{SDI}_{15}$ of permeates are relatively high even if a spiral wound reverse osmosis module could probably be fed by this water without severe clogging. The Total Organic Carbon of permeates is also analyzed (Fig 7).

\section{Insert Fig 7}

In average, the TOC concentration of permeates is equal to $2.4 \pm 0.8 \mathrm{mg}_{\mathrm{C}} \cdot \mathrm{L}^{-1}$ while organic carbon concentration coming from humic acids is equal to $0.68 \pm 0.03 \mathrm{mg}_{\mathrm{C}} \cdot \mathrm{L}^{-1}$ (Fig. 8).

\section{Insert Fig 8}

Hence, according to the standard deviations, the average permeate TOC concentration is more or less equal to the feeding one $\left(1.8 \pm 0.4 \mathrm{mg}_{\mathrm{C}} \cdot \mathrm{L}^{-1}\right)$ or even higher. In the latter case, the highest concentration into the permeates could be explained by the organic matter accumulation within the membrane module (in the retentate side). Indeed, backwashes are not efficient enough to remove all organics from the module as we could see later in this article (Fig. 10). Thus, the TOC concentration in the vicinity of the membrane surface would be higher than within the feed tank and assuming the rejection rate constant, more TOC could be passed through the membrane. Thus, the organic rejection rate is low. Similarly, Castaing et al. [47] obtained low total organic carbon rejection, ranging from 66 to $74 \%$, during the deadend filtration on $10 \mathrm{kDa}, 300 \mathrm{kDa}$ and $0.2 \mu \mathrm{m}$ submerged membranes of microalgae rich seawater.

Only $15 \%$ of humic acids are retained by the membrane. This rejection rate is low compared to Katsoufidou et al. 's results [31], who obtained a rejection rate equal to $60 \%$ during the ultrafiltration of a mixture containing humic acids, alginates, $\mathrm{NaCl}(20 \mathrm{mM})$ and $\mathrm{Ca}^{2+}(1$ $\mathrm{mM}$ ). Nevertheless, for our study, stock solutions of humic and alginic acids are pre-filtered with a $0.7 \mu \mathrm{m}$ filter which induces the removal of the biggest colloids from the raw seawater. For the first cycles of filtration and may be subsequently, the permeate contains less humic acids at the beginning of a cycle than afterwards (Fig. 8). The membrane module is never 
drained during operation therefore the water which is filtrated at the beginning of a cycle corresponds to that trapped in the module at the end of the backwash. Backwash water which leaves the plant at the end of the cycle " $n$ " contains less or as much humic acids as the seawater in the feed tank (Fig. 10). Thus, the average permeate collected during the first 5 minutes of the " $n+1$ " cycle contains less humic acids than the raw seawater especially since the permeate pipe still contains osmosed water of backwash; it dilutes the average permeate recovered at the beginning of each cycle.

\subsubsection{Backwash efficiency}

\subsubsection{Analysis of an average sample, representative of each backwash water}

The physico-chemical analyses of water coming from backwashes allow to determine the amount of total organic carbon withdrawn and that coming from humic acids (Fig. 9).

\section{Insert Fig 9}

The amount of TOC decreases drastically during the early backwash cycles and decelerates afterwards. The organic matter could be better removed from membrane surface and module in the early backwashes rather than after several cycles. At the beginning of the filtration, the organic matter would deposit directly on the membrane material versus heterogeneous fouling layer afterwards. The interactions between the organic matter and the membrane can be weaker than between organic matter ones which could explain the drop of organic matter inside backwash waters as ultrafiltration progresses.

The amount of recovered humic acids in the backwash waters seems to increase slightly as filtration progresses (Fig. 9). Backwash efficiency to remove humic acids could be enhanced during filtration. The amount of humic acids reaching the membrane and present in the permeates is relatively constant. Hence, the amount of humic acid that remains on the membrane surface after one backwash could decrease during ultrafiltration.

To sum up, the amount of TOC from backwash waters decreases while the organic matter coming from humic acids would increase slightly (Fig. 9). Hence, the alginic acid amount in the backwash waters could progressively decrease since organic matter is mainly brought by alginic and humic acids even if a part of the organics of feeding is not identified (Table 1). On the other hand, the amounts of alginic acids brought by the reconstituted seawater to the membrane are always constant and could slightly decrease in the permeates as the filtration progresses (Fig. 7 and 8). Higher accumulation of alginic acids, rather than humic acids, could 
occur on the membrane and pipe surfaces and/or in the piping and membrane module. More and more alginic acids could accumulate during the filtration. This result is consistent with the results obtained by Jermann et al. [42], Katsoufidou et al. [31] and Resosudarmo et al. [48] who found an increase of alginate rejection during the filtration.

\subsubsection{Analysis of fractionated sampling of water's backwashes}

Waters coming from backwashes numbered 1, 4, 7, 10,13, 16 are collected each and during five seconds in order to be analyzed (Fig. 10). Water volumes obtained during five seconds of backwash are added and placed on X-axis. For each volume, the amount of TOC and organic carbon from humic acids is determined; the cumulative values are indicated on $\mathrm{Y}$-axis.

\section{Insert Fig 10}

At the end of several backwashes, the velocity of recovery of TOC or organic matter coming from humic acids decreases since a plateau seems to be taking shape (Fig. 10 a, b). However, even after 30 seconds of backwash, organics are still recovered. Hence, the duration and/or intensity of backwashes are not sufficient to remove all organic matter from membrane or retentate compartment of membrane module.

The turbidity of backwash waters is almost constant for the early cycles of backwash and increases for the last ones (Fig. 10c). The amount of colloids and particles (alginic, humic acids, salts, kieselguhr and bentonite) alone or recombined could increase in the backwash waters. It is likely that colloids and particles accumulate not only on the fouled surfaces but also into the bulk of dead-end volumes of the plant. Indeed, it should be noted that no drainage of the membrane module or plant occurs while the installation is running.

\subsection{Discussion and summary}

It should be noted that the mechanisms of fouling which are assumed and described below, are established for a feed with organic carbon mainly brought by the humic acids containing several salts in high concentrations, in the presence of particles (bentonite and kieselguhr) and for specific conditions of dead-end filtration (PVDF membrane, $0.03 \mu \mathrm{m}$ of pore diameter, permeate flux equal to $100 \mathrm{~L} \cdot \mathrm{h}^{-1} \cdot \mathrm{m}^{-2}$, SFV equal to $50 \mathrm{~L} \cdot \mathrm{m}^{-2}$, etc.).

The operating conditions used for this study do not induce a lot of fouling and notably residual fouling which accounts on average for $20 \%$ of total fouling resistance (Fig.5). The 
fouling reversibility could be improved since deionized water has been used instead of permeate water for the backwashes [48, 49]. Moreover, no sharp change of fouling intensity is noted during the filtration since fouling resistance changes quasi linearly with time (Fig. 4 and 5). Therefore, the fouling layer seems not to be compressed at the transmembrane pressures which are reached in the present study contrary to Sioutopoulos and Karabelas [50] who observed a compression from a certain value of pressure beyond an initial phase of membrane coverage by alginate. Moreover, the fouling of membrane does not strongly affect the transmission rate of the humic acids since the permeate concentrations stay stable (Fig. 8). Concerning the TOC and alginic acids, the transmission rate (calculated from the concentrations in the feed tank) could be constant or be slightly decreased.

Most of the salts passes through the membrane since it has been verified that no change of conductivity between the feed and permeates was observed (results not shown). Nevertheless, a highly salted water is used for the present study $\left(\mathrm{NaCl} \sim 450 \mathrm{mM}, \mathrm{Ca}^{2+} \sim 10 \mathrm{mM}\right.$ and $\mathrm{Mg}^{2+}$ $\sim 50 \mathrm{mM}$ ) and a small amount of salts (not visible by measurements of conductivity) and more particularly divalent ones $\left(\mathrm{Ca}^{2+}\right.$ and $\left.\mathrm{Mg}^{2+}\right)$ could participate in the fouling mechanisms of humic and alginic acids [25, 27, 31]. Thus, Resosudarmo et al. [48] observed an increase of fouling phenomenon with a highly salted water $\left(\mathrm{NaCl} \sim 376 \mathrm{mM}\right.$ and $\mathrm{Ca}^{2+} \sim 8 \mathrm{mM}$ and $\mathrm{Mg}^{2+}$ $\sim 39 \mathrm{mM}$ ). Some "cationic bridges" could be formed between carboxylic groups of organic acids. Moreover, salts could mitigate the electrostatic repulsion between the membrane and compounds involved in the membrane fouling [25].

More and more humic acids seem to be recovered during backwashes, suggesting as previously observed $[27,31,48]$, their higher propensity to adsorb on virgin rather than already fouled membrane. Humic acids could have been irreversibly adsorbed on membrane material during the filtration of a mixture containing alginates, humic acids and $\mathrm{Ca}^{2+}$ inducing smaller membrane pore size followed by a rejection of alginates [42]. Thus, Humic acids could form a pre-layer favorable to the fouling of other compounds notably alginic acids.

Conversely, alginic acids seem preferentially removed by backwashes at the beginning of ultrafiltration and therefore would contribute to the initial reversible and final residual membrane fouling. Interactions between alginic acids and heterogeneous fouling layer/gel would be stronger than between alginic acids and the membrane. Thus, alginic acids could form a gel on the membrane surface which could become denser in the presence of calcium [48].

Results would seem to show that all particles and colloids are not removed from the membrane and/or retentate compartment during the early cycles of backwashes (Fig. 10c). 
Colloids and particles could participate in the fouling layer build-up. According to Jermann et al. [42], a cake composed by kaolinite alone is almost totally reversible contrary to a kaolinite - humic acids cake or a kaolinite - humic acids - alginate cake. Humic acids would adsorb on to kaolinite which would in turn accumulate on the membrane. It should be noted that the structure of the fouling layer will be different according to the inorganic particle concentration within the raw seawater. At low concentrations, fouling layer will be composed of particles remoted from each other. At higher concentrations, alginates and humic acids will accumulate inside the porous layer and will form a more compact gel than particles alone [42]. Nevertheless, the amount of inorganic particles brought to the membrane per cycle is close: $100 \mathrm{mg}$ for Jermann's study versus $140 \mathrm{mg}$ for this one. However, the membrane surfaces are different, $0.0042 \mathrm{~m}^{2}$ versus $0.28 \mathrm{~m}^{2}$ respectively.

\section{Conclusion:}

This work investigated the membrane fouling mechanisms during the dead-end ultrafiltration of synthetic seawater at $100 \mathrm{~L} \cdot \mathrm{h}^{-1} \cdot \mathrm{m}^{-2}$. Duration of filtration cycles equal to 30 minutes followed by backwash at $340 \mathrm{~L} \cdot \mathrm{h}^{-1} . \mathrm{m}^{-2}$ during 30 seconds allow a sustainable ultrafiltration during 8 hours. A graphical abstract gathers the main results obtained following the ultrafiltration of the synthetic seawater (Fig. 11). The fouling is mainly reversible. The deposit/gel and adsorbates do not induce a high increase of transmembrane pressure meaning high fouling. The deposit/gel would remain fairly permeable since almost all the humic acids and more generally total organic carbon passes through the membrane throughout operation. Less and less organics are withdrawn by backwash waters during the operation even if more and more humic acids are recovered (Fig. 11). Mechanisms of fouling seem to change during the ultrafiltration according to the state of the membrane, pristine or already fouled: during the early stages of filtration, humic acids could preferentially participate in the membrane fouling compared with alginic acids whereas their magnitude would be reversed after several sequences of filtration/backwash. Colloids and particulates of seawater could be retained in the heterogeneous fouling layer and/or accumulate in the concentrate compartment of the membrane module before being recovered inside backwash waters. In order to confirm several assumptions enounced during the present work, future researches on fouling layer autopsies during ultrafiltration should be undertaken. These autopsies would allow better understanding of the fouling mechanisms. 


\section{References:}

[1] Maurel A. 2006. Dessalement de l'eau de mer et des eaux saumâtres et autres procédés non conventionnels d'approvisionnement en eau douce, Paris, Editions Tech\&Doc., 286p.

[2] Massé A., Nguyen Thi H., Legentilhomme P., Jaouen P., 2011, Dead-end and tangential ultrafiltration of natural salted water : influence of operating parameters on performance and energy consumption. Journal of Membrane Science 380, 192-198.

[3] Sabiri N.-E., Castaing J. B., Massé A., Jaouen P., 2012. Performance of a sand filter in removal of micro-algae from seawater in aquaculture production systems. Environmental Technology 33 (4-6) 667-676.

[4] Plantier S., Castaing J.-B., Sabiri N.-E., Massé A., Jaouen P., Pontié M., 2013. Performance of a sand filter in removal of algal bloom for SWRO pre-treatment. Desalination and Water Treatment 51 (7-9) 1838-1846.

[5] Guilbaud J., Massé A., Wolff F.-C., Jaouen P., 2013. Seawater pretreatment by dead-end micro and ultrafiltration in pressure-driven inside feed. Desalination and water treatment 51 (1-3) 416-422.

[6] Haure J., Hussenot J., Buzin F., Lassus P., Marcaillou C., Mondeguer F., Séchet V., Royer F., Amzil Z., Cardinal M., Le Grel L., Massé A., Sabiri N.-E., Castaing J.-B., Jaouen P. 2014. Molluscan shellfish safety, chapter 3: Storage and Detoxification of Bivalve Molluscs as a Tool in a Marketing Strategy, Sauvé, Gilbert (Ed.), XXVI, 261 p., ISBN 978-94-007-6588-7.

[7] Van Hoof S., Minnery J., Mack B., 2001. Dead-end ultrafiltration as alternative pretreatment to reverse osmosis in seawater desalination: a case study. Desalination 139, 161168.

[8] Xu J., Ruan G., Gao X., Pan X., Su B., Gao C., 2008. Pilot study of inside-out and outside in hollow fiber UF modules as direct pretreatment of seawater at low temperature for reverse osmosis. Desalination 219 (1-3), 179-189. 
[9] Knops F., Van Hoof S., Futselaar H., Broens L., 2007. Economic evaluation of a new ultrafiltration membrane for pretreatment of seawater reverse osmosis. Desalination 203 (1-3), 300-306.

[10] Zhang J.D., Liu Y.W., Gao S.M., Li C.Z., Zhang F., Zen H.M., Ye C.S., 2006. Pilot testing of outside-in UF pretreatment prior to RO for high turbidity seawater desalination. Desalination 189 (1-3), 269-277.

[11] Xu J., Chang C.Y., Gao C., 2010. Performance of a ceramic ultrafiltration membrane system in pretreatment to seawater desalination. Separation and Purification Technology 75 , 165-173.

[12] Pearce G., 2007. Introduction to membranes: Manufacturers' comparison: Part 3, Filtration + Separation, December 2007, 30-33.

[13] Xu J., Ruan L. G., Wang X., Jiang Y.Y., Gao L.X., Gao J.C., 2012. Ultrafiltration as pretreatment of seawater desalination: critical flux, rejection and resistance analysis. Separation and Purification Technology 85, 45-53.

[14] Knops F. and Horvath F., 2009. UF pretreatment for cold seawater RO. Desalination \& Water Reuse 19.

[15] Voutchkov N., 2010. Seawater pretreatment, Bangkok, Edition: Water treatment academy, $173 \mathrm{p}$.

[16] Gasia-Bruch E., Sehn P., Garcia-Molina V., Markus B., Ofer R., Mino N., 2011. Field experinence with a $20,000 \mathrm{~m}^{3} / \mathrm{d}$ integrated membrane seawater desalination plant in Cyprus. Presented at EuroMed 2010 - Desalination for Clean Water and Energy: Cooperation among Mediterranean Countries of Europe and MENA Region, Tel Aviv, Israel.

[17] Heijman S.G.J., Kennedy M.D., Van Hek G.J., 2005. Heterogeneous fouling in dead-end ultrafiltration. Desalination 178 (1-3), 295-301. 
[18] Jezowska A., Bottino A., Capannelli G., Fabbri C., Migliorini G., 2009. Ultrafiltration as direct pre-treatment of seawater: a case study. Desalination 245 (13), 723-729.

[19] Benner R., Biddanda B., Black B, McCarthy M., 1997. Abundance, size distribution, and stable carbon and nitrogen isotopic compositions of marine organic matter isolated by tangential-flow ultrafiltration. Marine chemistry 57, 243-263.

[20] McCarthy M., Hedges J., Benner R., 1996. Major Biochemical composition of dissolved high molecular weight organic matter in seawater. Marine Chemistry 55, 281-297.

[21] Kennish M., 2001. Practical Handbook of marine Science, CRC press, 876p.

[22] Moonkhum M., Lee Y., Seok Y., 2010. Review of seawater natural organic matter fouling and reverse osmosis transport modeling for seawater reverse osmosis desalination. Desalination and Water treatment 15, 92-107.

[23] Ittekkot V., Brockmann U., Michaelis W., Degens E., 1981. Dissolved free and combined carbohydrates during a phytoplankton bloom in the northern North Sea, Marine Ecology - Progress Series 4, 299-305.

[24] Biersmith A. and Benner R., 1998. Carbohydrates in phytoplancton and freshly produced dissolved organic matter. Marine Chemistry 63, 131-144.

[25] Li Q. and Elimelech M., 2004. Organic fouling and chemical cleaning of nanofiltration membranes: measurements and mechanisms. Environmental Sciences and Technology 38, $4683-4693$.

[26] Ye, Y., Le Clech, P., Chen, V., Fane, A.G., Jefferson, B., 2005. Fouling mechanisms of alginate solutions as model extracellular polymeric substances. Desalination 175 (1 SPEC. ISS.), 7-20.

[27] Jermann D., Pronk W., Meylan S., Boller M., 2007. Interplay of different NOM fouling mechanism during ultrafiltration for drinking water production. Water research 41, 17131722. 
[28] Baghoth, S.A., Maeng, S.K., Salinas Rodriguez, S.G., Ronteltap, M., Sharma, S., Kennedy, M., Amy, G.L., 2008. An urban water cycle perspective of natural organic matter (NOM): NOM in drinking water, wastewater effluent, storm water, and seawater. Water Science and Technology: Water Supply 8 (6), 701-707.

[29] Katsoufidou K., Yiantsios S., Karabelas A., 2005. An experimental study of UF membrane fouling by humic acids and sodium alginate solutions: the effect of backwashing on flux recovery. Desalination, 220, 214-227.

[30] Katsoufidou K., Yiantsios S., Karabelas A., 2008. An experimental study of UF membrane fouling by humic acid on flux recovery Desalination 220, 214-227.

[31] Katsoufidou K., Sioutopoulos D., Yiantsios S., Karabelas A., 2010. UF membranes fouling by mixtures of humic acids and sodium alginate: Fouling mechanism and reversibility. Desalination 264, 220-227.

[32] Gray, S.R., Dow, N., Orbell, J.D., Tran, T., Bolto, B.A., 2011. The significance of interactions between organic compounds on low pressure membrane fouling. Water Science and Technology 64 (3), 632-639.

[33] Katsoufidou K., Yiantsios S., Karabelas A., 2007. Experimental study of microfiltration membrane fouling by sodium alginate and flux recovery by backwashing. Journal of membrane science $300,137-146$.

[34] Van den Brink P., Zwijnenburg A., Smith G., Temmink H., Van Loosdrecht M., 2009. Effect of free calcium concentration and ionic strength on alginate fouling in cross-flow membrane filtration. Journal of Membrane Science 345, 207-216.

[35] Zazouli M., Nasseri S, Ulbricht M., 2010. Fouling effects of humic and alginic acids in nanofiltration and influence of solution composition. Desalination 250, 688-692. 
[36] Cornelissen, E.R., Siegers, W.G., Ogier, J., Beerendonk, E.F., 2006. Influence of Calcium-NOM Complexes on Fouling of Nanofiltration Membranes in Drinking Water Production. Water Science and Technology 4 (6), 171-178.

[37] Copin-Montégut G., 1991. Chimie de l'eau de mer, Institut Océanographique.

[38] Gaid K. and Treal Y., 2007. Le dessalement des eaux par osmose inverse: l'expérience de Véolia Water. Desalination 203, 1-14.

[39] Leparc, J., Rapenne S. Courties C., Lebaron P. Croué J.-P., Jacquemet V., Turner G., 2007. Water quality and performance evaluation at seawater reverse osmosis plants through the use of advanced analytical tools. Desalination 203, 243-255.

[40] Petry M., Sanz M., Langlais C., Bonnélye V., Durand JU.-P., Guevara D., Mantovani Nardes W., Homma Saemi C., 2007. The El Coloso (Chile) reverse osmosis plant. Desalination 203, 141-152.

[41] Kennedy, M., Kamanyi, J., Heijman, B., Amy, G., 2008. Colloidal organic matter fouling of UF membranes: roles of NOM composition and size. Desalination 220, 200-213.

[42] Jermann D., Pronk W., Kägi R., Halbeisen M., Boller M., 2008. Influence of interactions between NOM and particules on UF fouling mechanisms. Water research 42, 3870-3878.

[43] Huang H., Lee N., Young T., Amy G., Lozier J., Jacangelo J. 2007. Natural organic matter fouling of low-pressure, hollow-fiber membranes: effects of NOM source and hydrodynamic conditions, Water Research, 41, 3823-3832.

[44] Kimura K., Hane Y., Watanabe Y., Amy G., Ohkuma N., 2004. Irreversible membrane fouling during ultrafiltration of surface water. Water Research, 38, 3431-3441.

[45] Castaing, J.-B., Massé, A., Séchet, V., Sabiri N.-E ., Pontié., M., Haure, J., Jaouen, P., 2011. Immersed hollow fibres microfiltration (MF) for removing undesirable micro-algae and protecting semi-closed aquaculture basins. Desalination 276, 386-396. 
[46] Massé A., Nguyen Thi H., Roelens G., Legentilhomme P., Jaouen P., 2013. Seawater ultrafiltration: role of particles on organic rejections and permeate fluxes. Environmental Technology 34 (17) 2553-2561.

[47] Castaing, J.-B., Massé, A., Pontié, M., Séchet, V., Haure, J., Jaouen, P., 2010. Investigating submerged ultrafiltration (UF) and microfiltration (MF) membranes for seawater pre-treatment dedicated to total removal of undesirable micro-algae. Desalination 253, 71-77.

[48] Resosudarmo A., Ye Y., Le-Clech P., Chen V., 2013. Analysis of UF membrane fouling mechanisms caused by organic interactions in seawater. Water research 17, 911-921.

[49] Li S., Heijman S.G.J., Verberk J.Q.J.C., Amy G.L., Van Dijk J.C., 2012. Seawater ultrafiltration fouling control: Backwashing with demineralized water/SWRO permeate. Separation and Purification Technology 98, 327-336.

[50] Sioutopoulos D., Karabelas A., 2015. The effect of permeation flux on the specific resistance of polysaccharide fouling layers developing during dead-end ultrafiltration. Journal of membrane science $473,292-301$. 


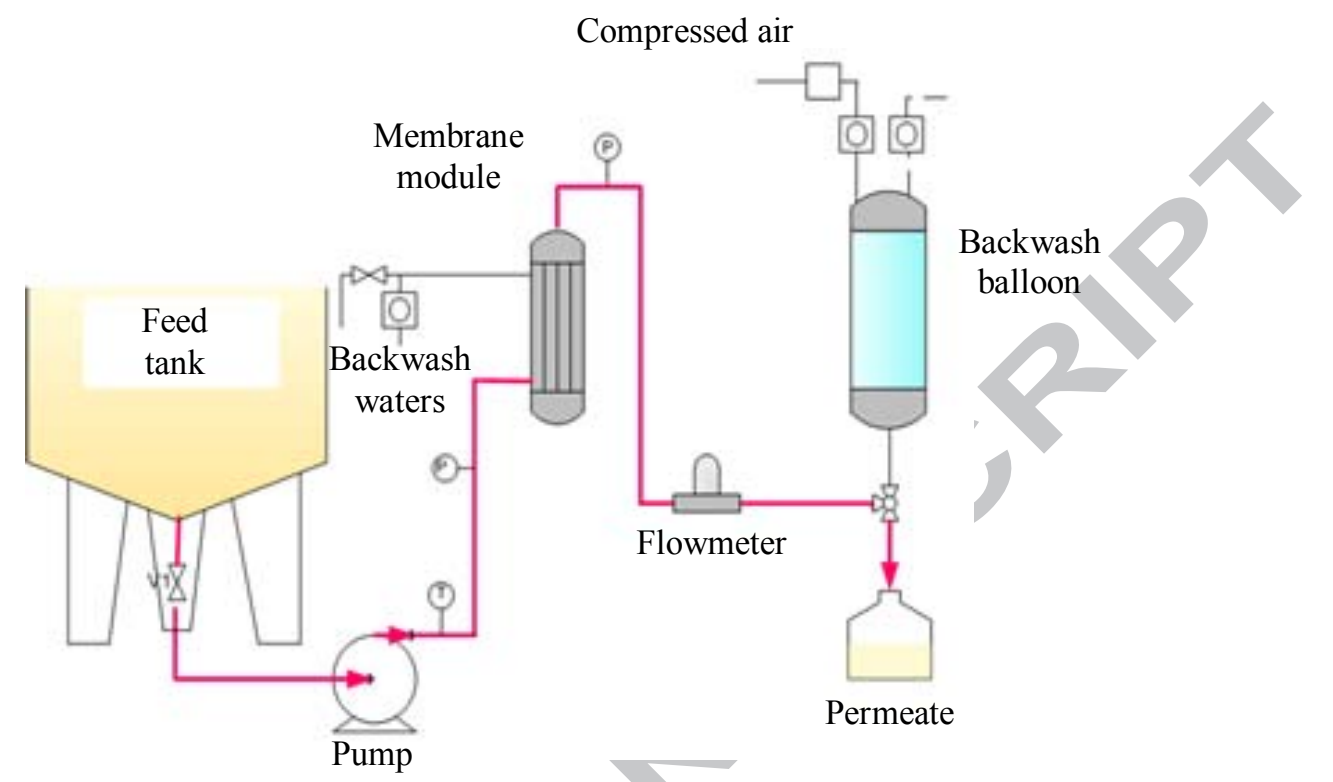

Fig. 1: Experimental set-up 


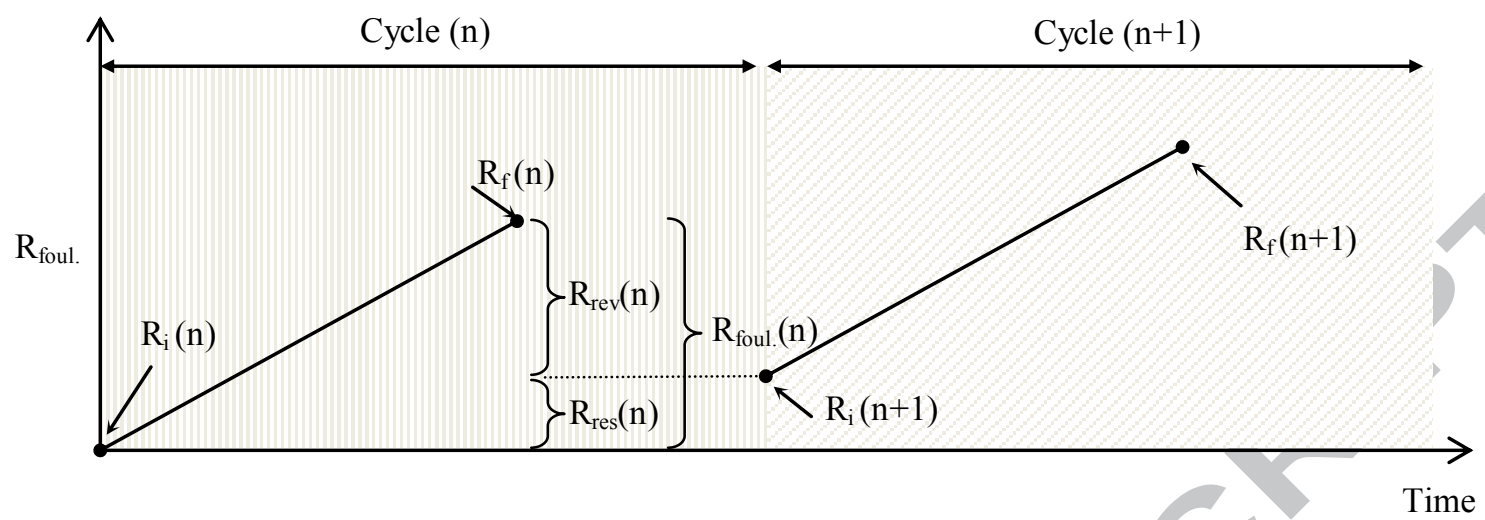

Fig. 2: Fouling resistance distribution and definition during filtration (for this work, there is almost linearity between fouling resistance and time) 

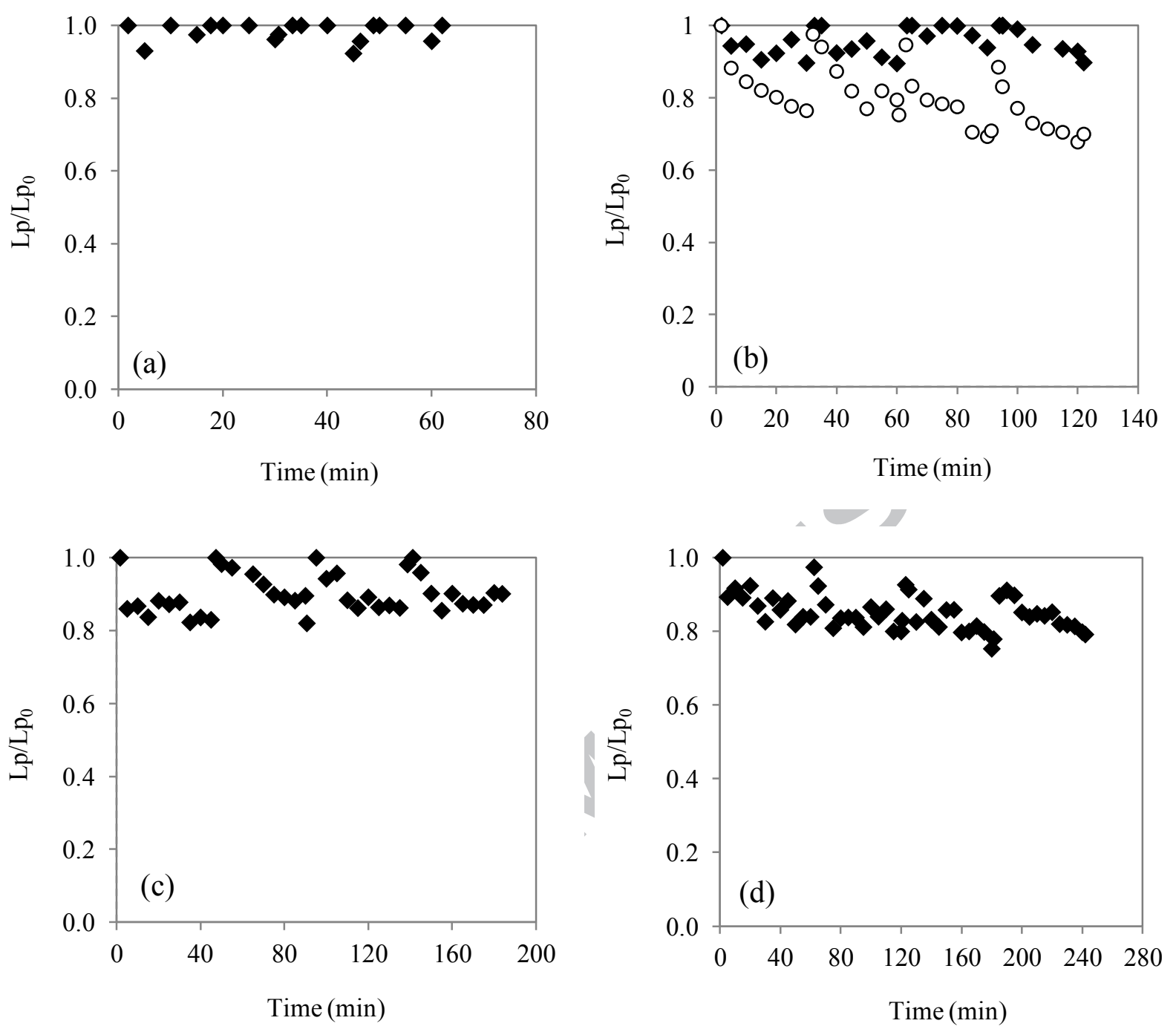

Fig. 3: Normalized permeability at $20^{\circ} \mathrm{C}$ during filtration of synthetic ( $\bullet$ ) and natural seawater (o) at 100 L.h $\mathrm{h}^{-}$ ${ }^{1} \cdot \mathrm{m}^{-2}$ for specific filtered volumes equal to $25 \mathrm{~L} \cdot \mathrm{m}^{-2}$ (a), $50 \mathrm{~L} \cdot \mathrm{m}^{-2}$ (b), $75 \mathrm{~L} \cdot \mathrm{m}^{-2}$ (c), $100 \mathrm{~L} \cdot \mathrm{m}^{-2}$ (d) 


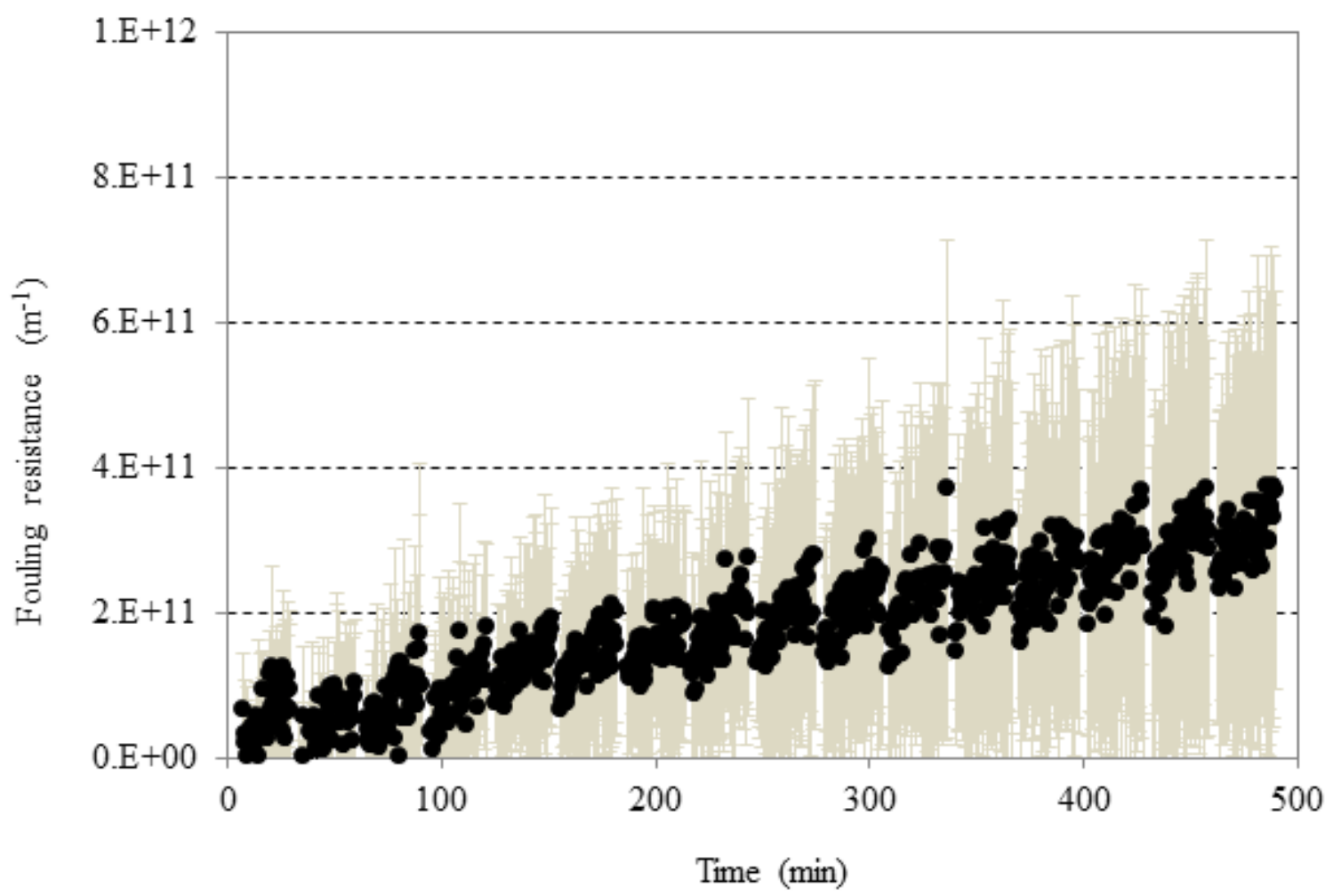

Fig. 4: Average fouling resistance $\left(\mathrm{R}_{\text {foul. }}\right)$ changes during ultrafiltration of synthetic seawater. Strokes represent the standard deviations on the 4 experiments. 


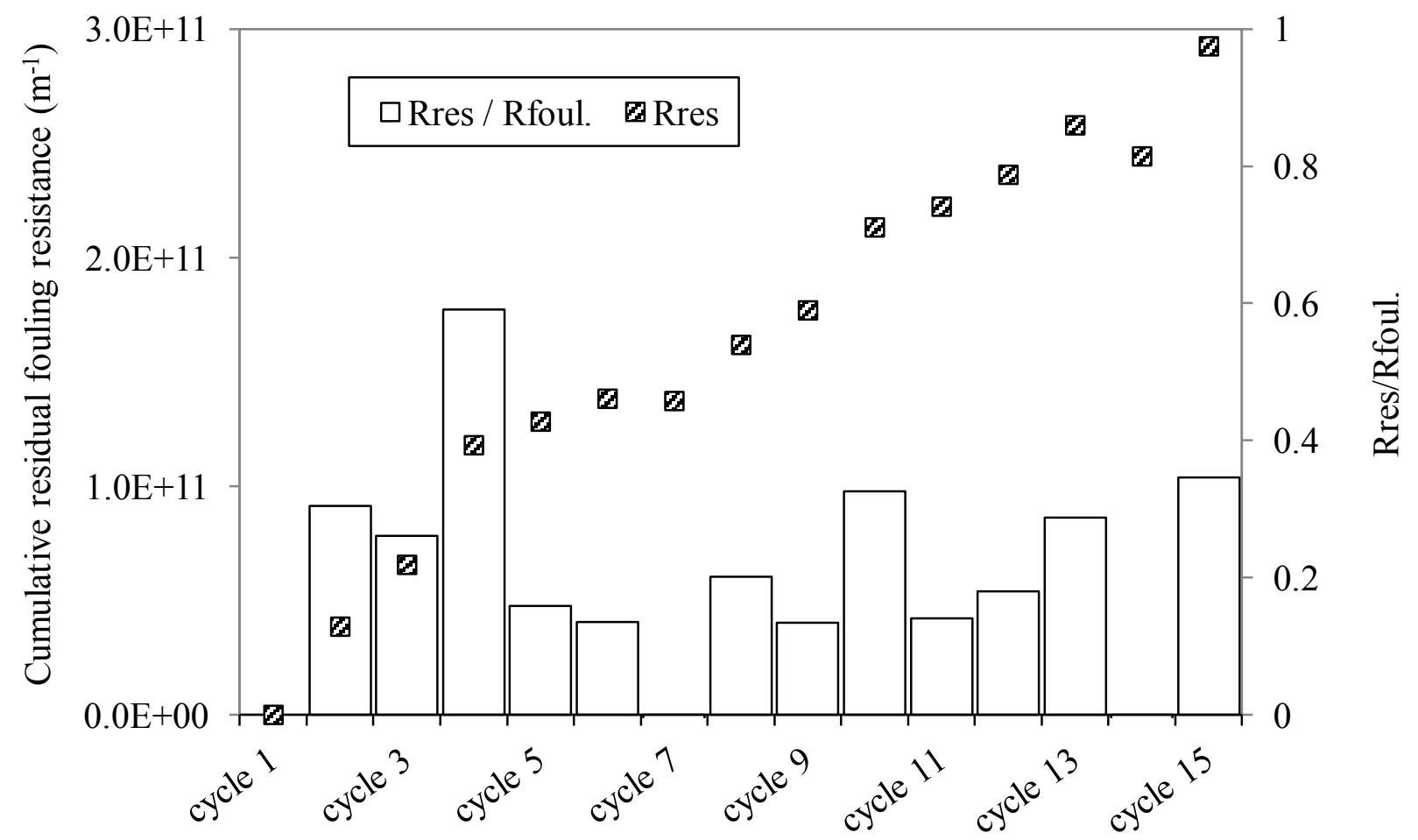

Fig. 5: Changes of cumulative residual fouling resistances as well as residual/total fouling resistance ratio during the ultrafiltration of synthetic seawater 

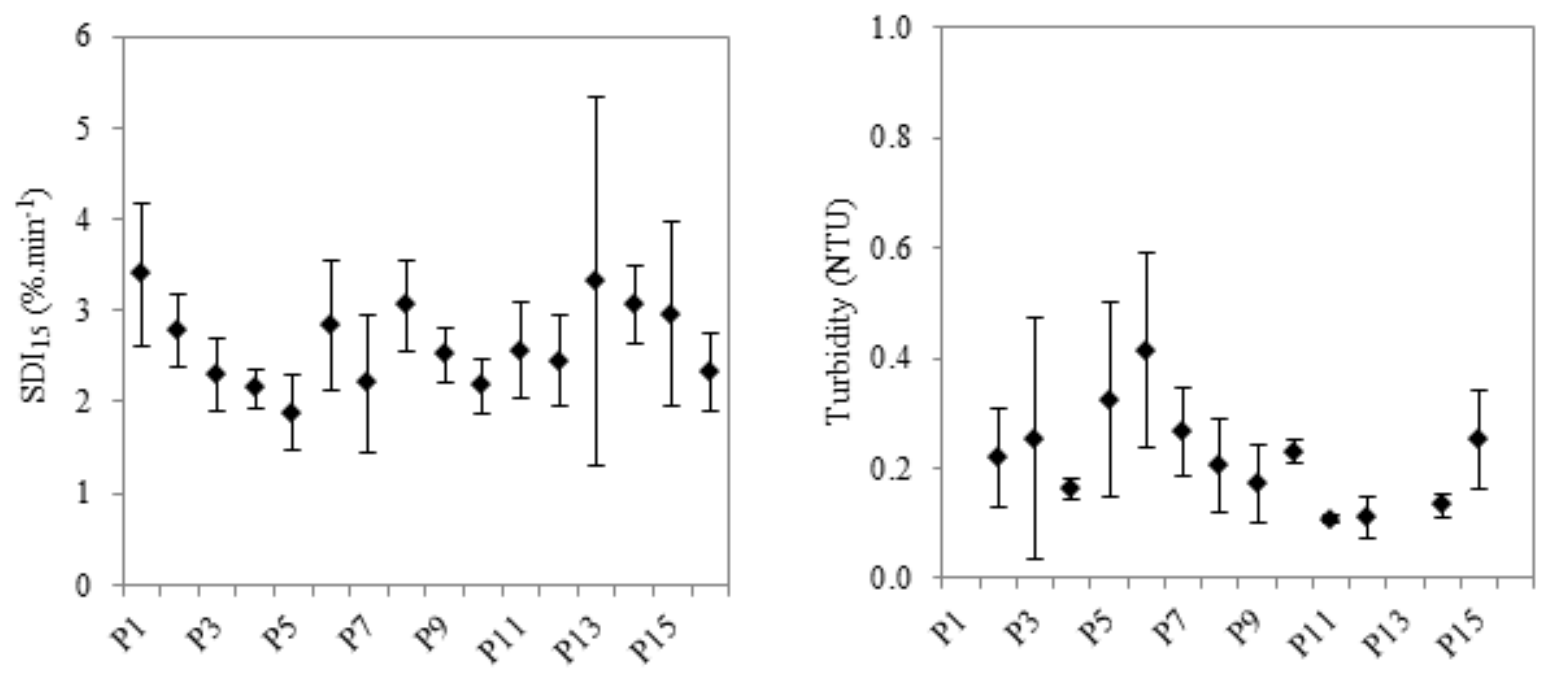

Fig. $6: \mathrm{SDI}_{15}$ and turbidity values of permeates. $\mathrm{P}_{\mathrm{i}}$ designates the sample of permeate recovered during the $\mathrm{i}^{\text {th }}$ filtration cycle. Average results of four experiments. 


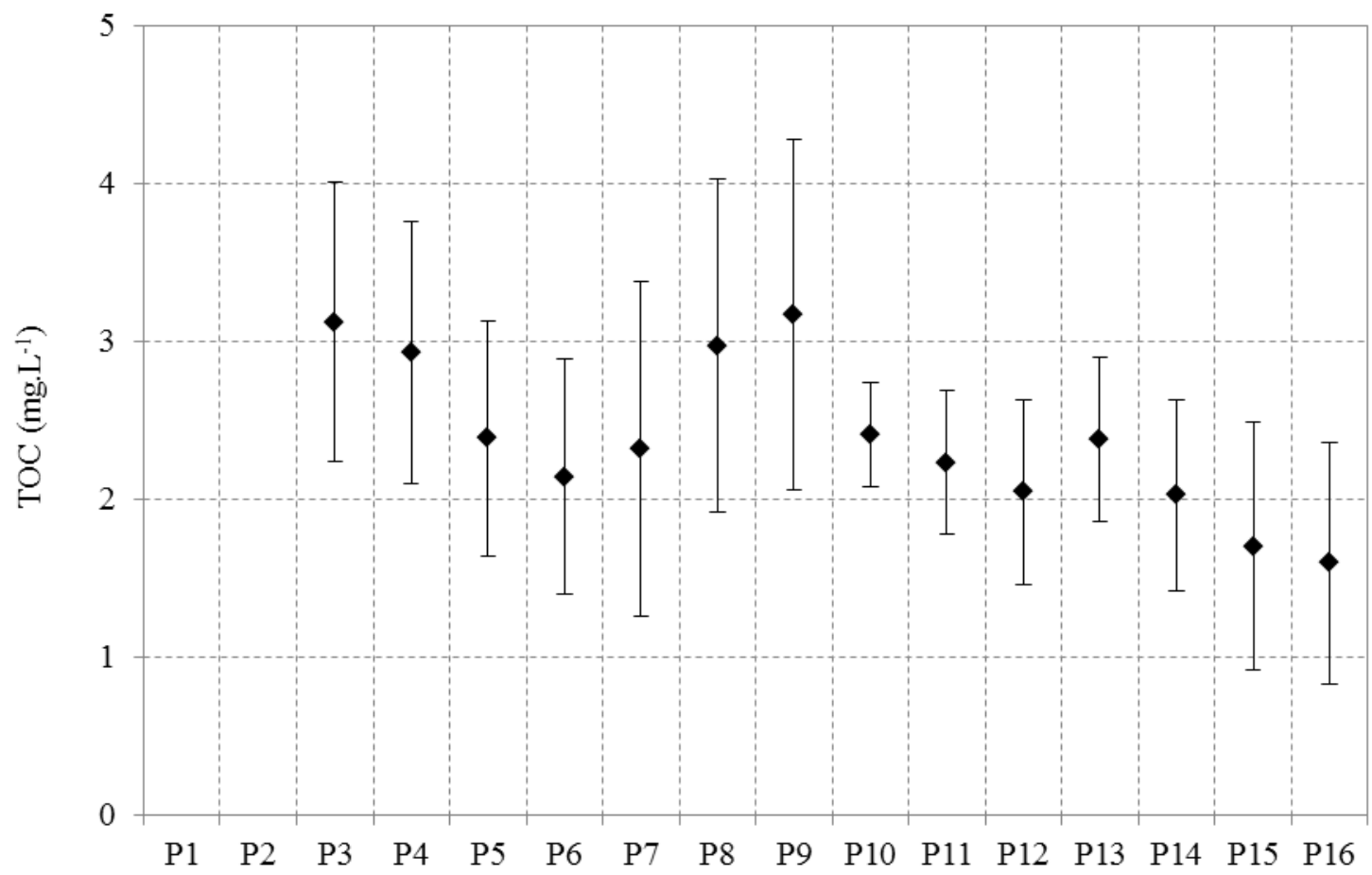

Fig. 7 : Total organic carbon (TOC) concentration of permeates (average results of four experiments). $\mathrm{P}_{\mathrm{i}}$ designates the sample of permeate recovered during the $\mathrm{i}^{\text {th }}$ filtration cycle. For the first four cycles of filtration, the permeates are recovered during and all five minutes of filtration. 


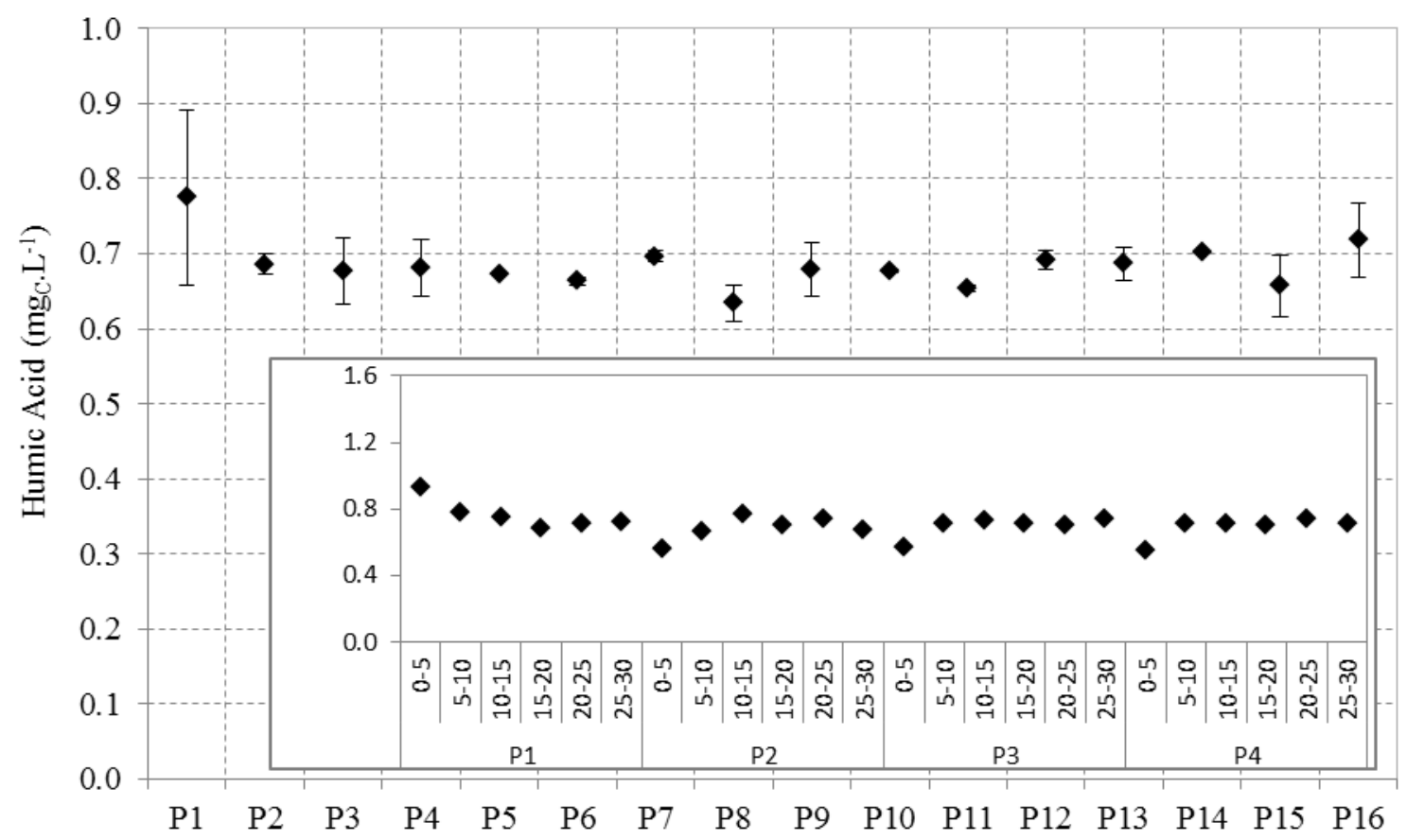

Fig. 8: Organic carbon concentration of permeates brought by humic acids (average results of two experiments). $\mathrm{P}_{\mathrm{i}}$ designates the sample of permeate recovered during the $\mathrm{i}^{\text {th }}$ filtration cycle. For the first four cycles of filtration, the permeates are recovered during and all five minutes of filtration. 


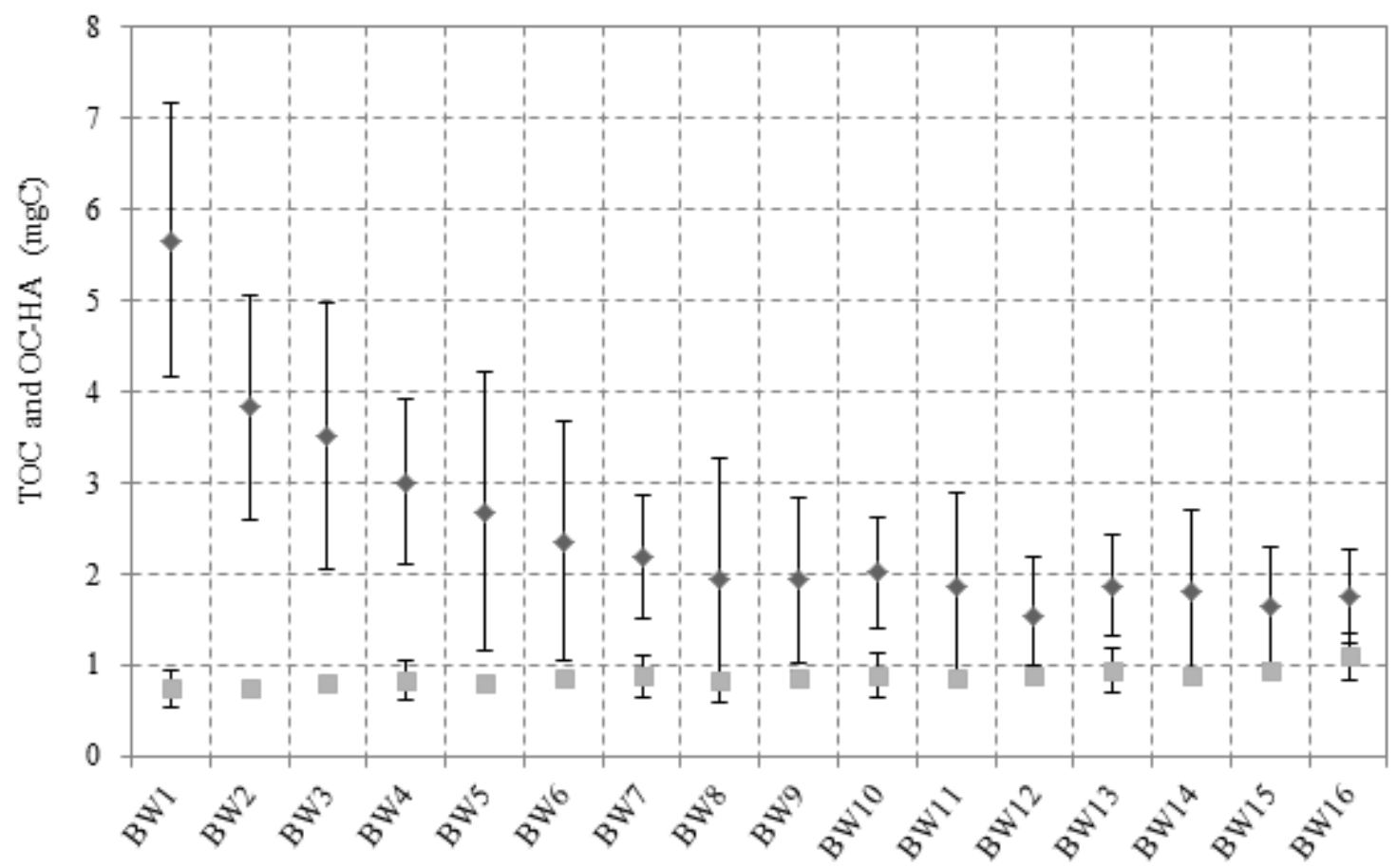

Fig. 9 Amount of Total organic carbon (TOC) and organic carbon from humic acids (OC-HA) in the backwash waters (BW) 

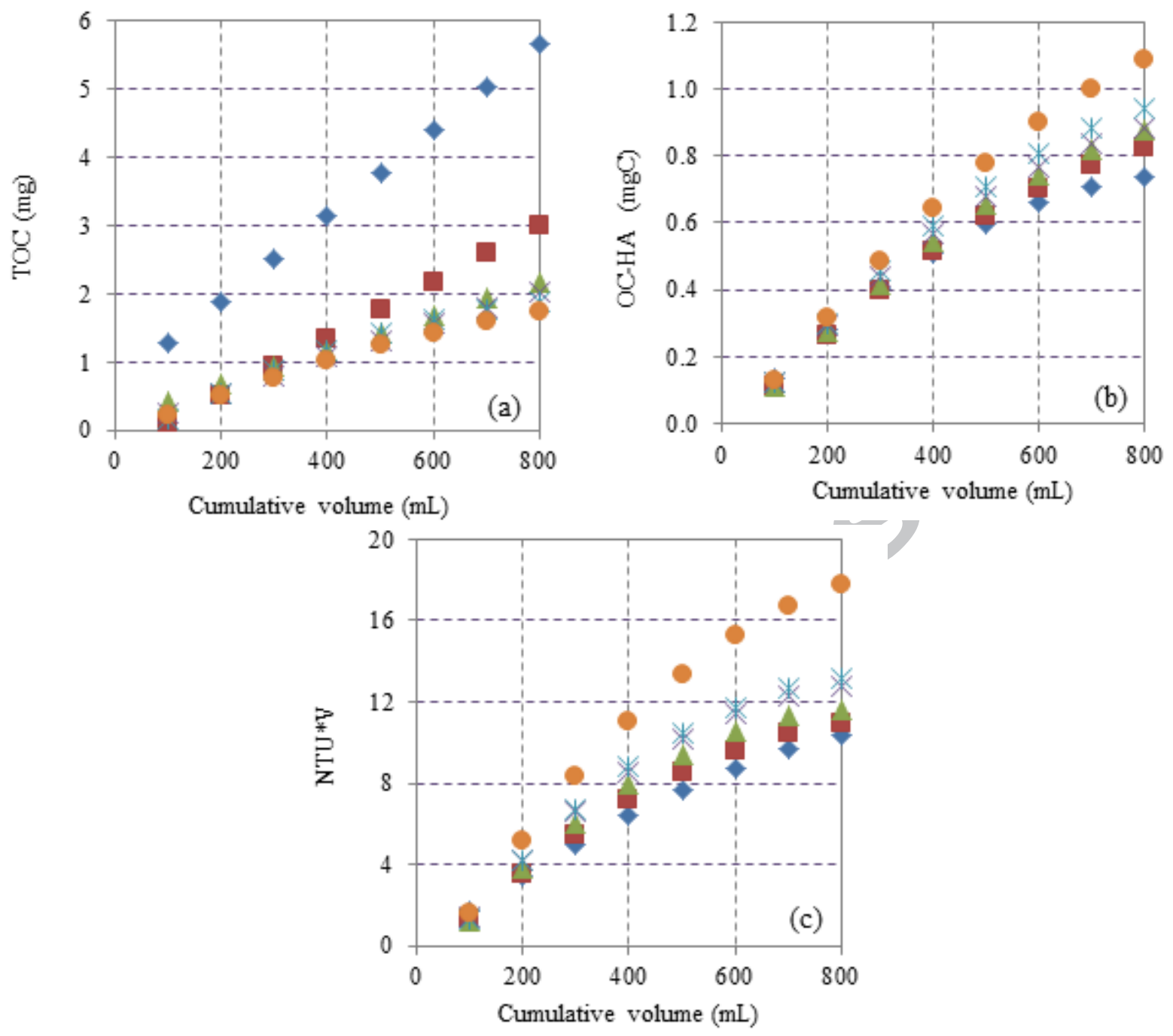

BW1

BW4

$\triangle$ BW7

$\times$ BW10

* BW13

BW16

Fig. 10: Changes of the cumulative amount of the Total Organic Carbon (TOC) (a) Organic carbon from humic acids (b) and turbidity (c) of waters sampled each and during five seconds of the backwashes numbered 1, 4, 7, $10,13,16$. 


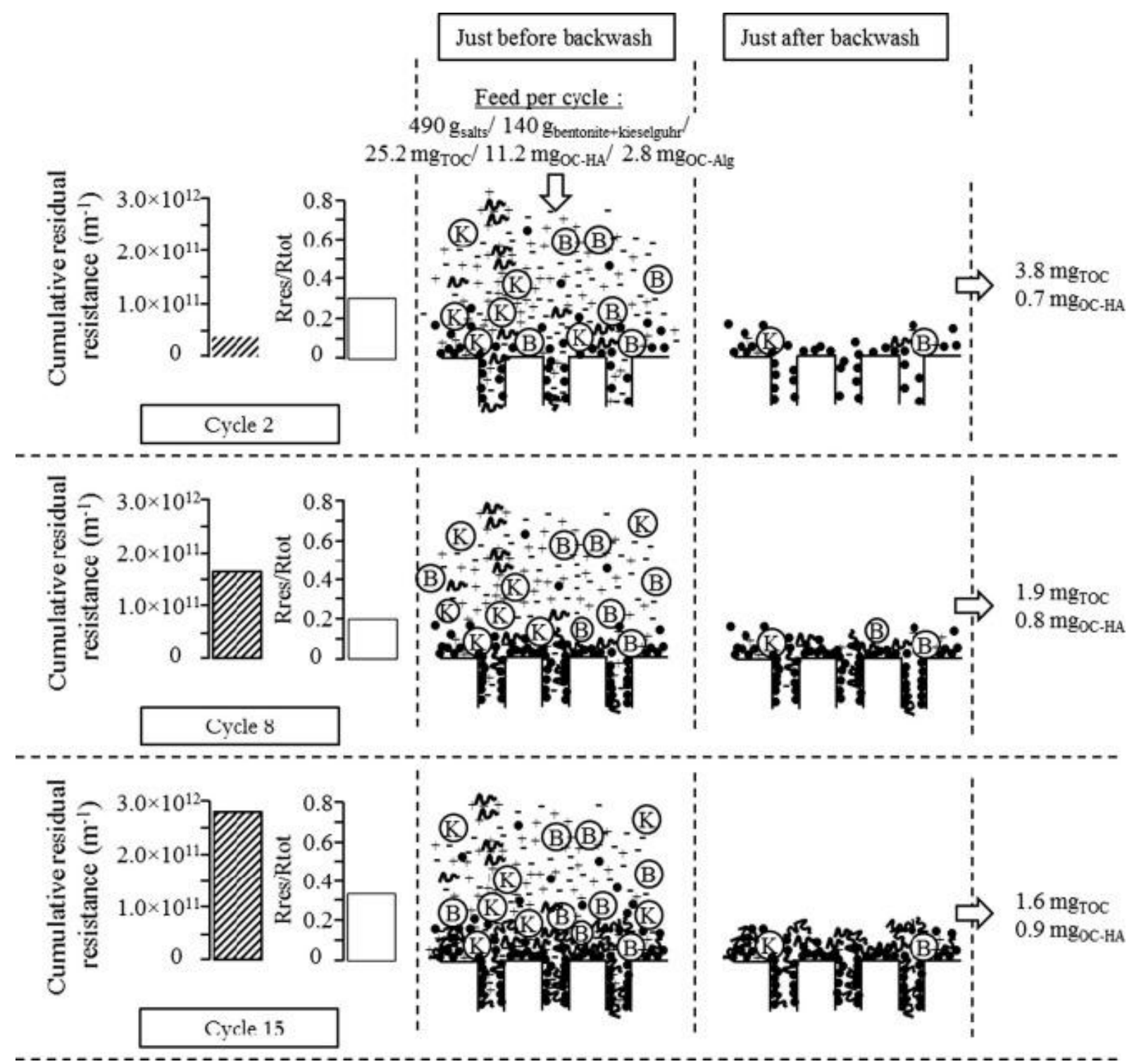

Fig. 11.

Graphical abstract of fouling mechanisms during ultrafiltration of the synthetic seawater (TOC: total organic carbon, OC-HA organic carbon from humic acids, OC-Alg: organic carbon from alginic acids). 
Table 1: Characteristics of the prepared seawater and natural seawaters sampled at different worldwide locations $[17-22,35-40]$

\begin{tabular}{|c|c|c|}
\hline & $\begin{array}{c}\text { Prepared seawater } \\
\text { (average on } 4 \text { synthetic seawaters) }\end{array}$ & Natural seawater \\
\hline Turbidity (NTU) & $3.1 \pm 0.5$ & $0.1-20$ \\
\hline $\mathrm{pH}$ & $7-8$ & $4-8.5$ \\
\hline Suspended solids $\left(\mathrm{mg} \mathrm{L}^{-1}\right)$ & $8.7 \pm 1,7$ & - \\
\hline Humic acids $\left(\mathrm{mg}_{\mathrm{C} \cdot \mathrm{L}^{-1}}\right)$ & 0.8 & - \\
\hline Alginic acids $\left(\mathrm{mg}_{\mathrm{C}} \cdot \mathrm{L}^{-1}\right)$ & 0.2 & - \\
\hline $\mathrm{SDI}_{15}(\% / \mathrm{min})$ & $>6.6$ & $>6.6$ \\
\hline TOC $\left(\mathrm{mg} \cdot \mathrm{L}^{-1}\right)$ & $1.8 \pm 0,4$ & $0.8-4.0$ \\
\hline Conductivity $\left(20^{\circ} \mathrm{C}\right)\left(\mathrm{mS} . \mathrm{cm}^{-1}\right)$ & $42 \pm 3$ & $49-62$ \\
\hline$[$ Salts $]\left(\mathrm{mg} \cdot \mathrm{L}^{-1}\right)$ & $34684 \pm 3$ & \\
\hline $\mathrm{Na}^{+}$ & $10074 \pm 13$ & $10945-15000$ \\
\hline $\mathrm{K}^{+}$ & $332 \pm 1$ & $383-690$ \\
\hline $\mathrm{Mg}^{2+}$ & $1274 \pm 56$ & $1334-1660$ \\
\hline $\mathrm{Ca}^{2+}$ & $414 \pm 6$ & $405-780$ \\
\hline $\mathrm{Cl}^{-}$ & $20173 \pm 38$ & $19080-26500$ \\
\hline $\mathrm{Br}^{-}$ & $73 \pm 1$ & $45-67$ \\
\hline $\mathrm{NO}_{3}^{-}$ & $158 \pm 1$ & $0.2-25$ \\
\hline $\mathrm{SO}_{4}^{2-}$ & $2185 \pm 15$ & $2400-2965$ \\
\hline
\end{tabular}




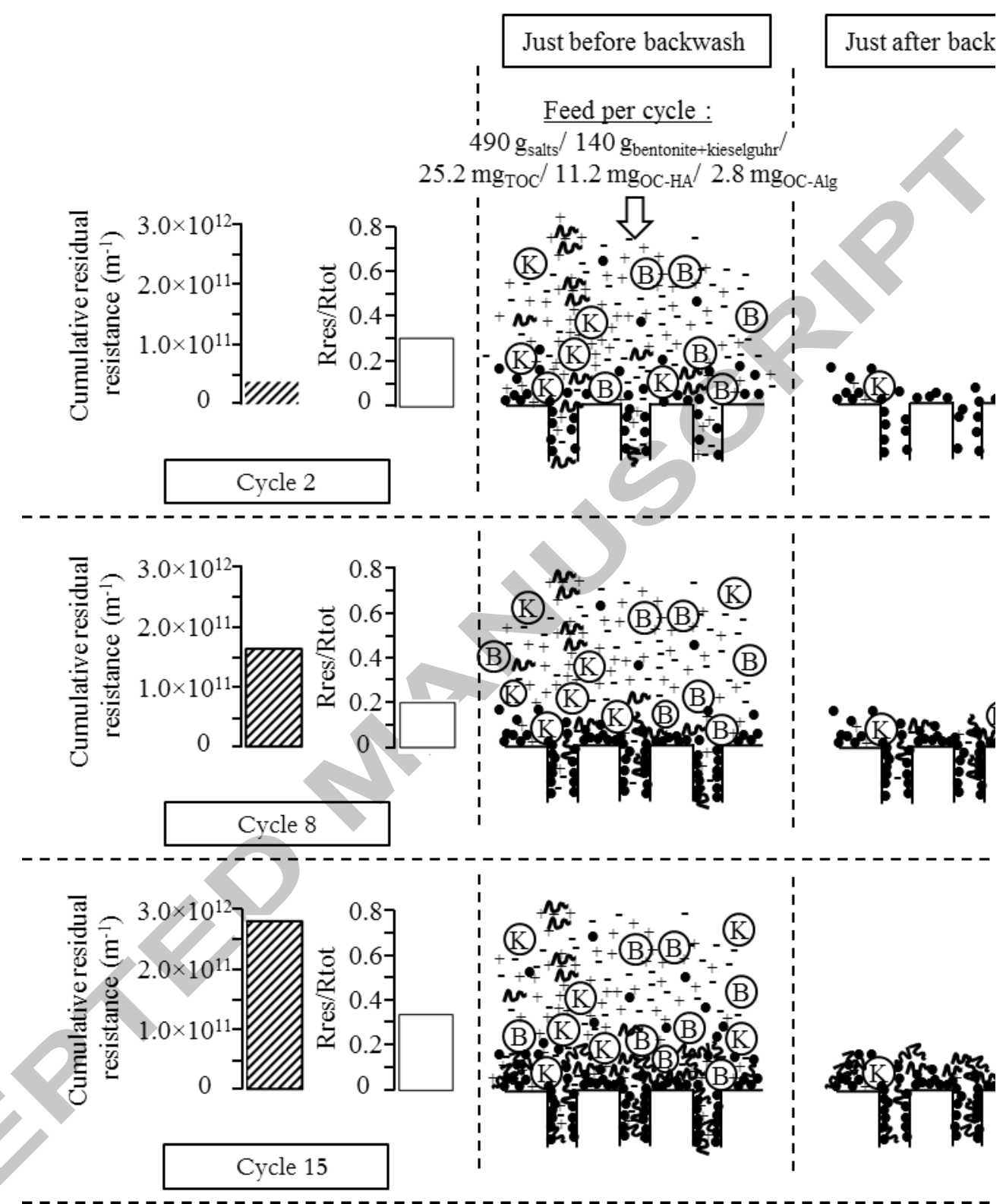

Graphical abstract of fouling mechanisms during ultrafiltration of the synthetic seawater (TOC: total organic carbon, OC-HA organic carbon from humic acids, OC-Alg: organic carbon from alginic acids) 